\title{
Power-up school library media centers: New York library power
}

\author{
Melinda GReenblatt
}

\author{
SHEILA Salmon \\ NEW VISIONS FOR PUBLIC SCHOOLS, 96 Morton Street, $6^{\text {th }}$ \\ floor, New York, New York 10014, email: \\ ssalmon@newvisions.org
}

\begin{abstract}
The National Library Power program, funded by the DeWitt Wallace-Reader's Digest Fund, was designed to create public elementary and middle school library programs that improve teaching and leaming. Using the school library media program as a catalyst for school reform, the Library Power program demonstrated how to change the role of the school librarian. During its eight-year grant period, New Visions for Public Schools' professional development program taught participants how to administer a collaboratively planned, flexible access library, and address issues such as management, collection development, and technology. The authors describe its features and its applicability to other school systems.
\end{abstract}

The National Library Power program, funded by the DeWitt Wallace-Reader's Digest Fund, created public elementary and middle school library programs that improve teaching and learning in nineteen communities across the United States. Using the school library media program as a catalyst for school reform, the Library Power program demonstrates new ways of educating young people by changing the role of the school library media specialist.

New York City was the first recipient of the Library Power grant and over the course of this eight-year initiative, New Visions for Public Schools, a private not-for profit public education organization that aims to improve the quality of education children receive in New York City's public schools, developed a comprehensive professional staff development program for school librarians, teachers and administrators in elementary schools. Our challenge was to find elementary schools that were eager to adopt a new program that would require a full-time librarian, a flexible access library program and commitment to support collaborative teaching and planning. In addition to selecting the schools, renovating the libraries, and adding resources to the collection we also had to fashion a professional development program that would meet the needs of the librarians, most of whom had no professional library training and of all of whom were unfamiliar with the philosophy of the program. Over the eight years, we worked with over one hundred and sixty schools and provided more than two hundred professional development opportunities for hundreds of teachers, librarians, school administrators and parents.

The focus of the professional development program we crafted was to position the library as the center of literacy in the school and the librarian as an information specialist,

Education for All: Culture, Reading and Information, IASL, 1998 
curriculum expert, and teaching partner. Our mission was to teach participants how to develop and administer a school library media center program that encouraged flexible access for individuals, small groups, and whole classes, and utilized a collaboratively planned teaching program that connected school librarian to classroom teachers and subject specialists in a partnership that improved teaching and learning. We also addressed the issues of library management and technical operations, collection development, technology, communications and public relations, and other facets of a librarian's professional life.

Our program of professional development encompassed a wide-range of activities and initiatives including:

- Writing a handbook for librarians which was recently revised and published as, Power Up Your Library: Creating the New Elementary School Library Program (Libraries Unlimited, 1996).

- Producing bibliographies (some of which now appear on the web site of New Visions for Public Schools).

- Organizing monthly meetings for participants.

- Visiting participating schools for on-site consultation and technical assistance.

- Conducting an annual book and software exhibit.

- Instituting technology workshops.

- Leading workshops for teams of teachers and librarians.

- Developing meetings and institutes for teams of administrators, teachers and parents.

\section{Monthly Meetings}

Monthly meetings of participating librarians was the single most important element of our staff development program. From the beginning of the project, librarians were expected to attend these meetings held mainly in schools, but also in public libraries and cultural institutions. Most of the presentations at the full-day meetings were given or facilitated by our own staff, which included six librarians with many years of experience in school, public and special libraries. Groups were limited to thirty people or less in order to encourage participation in hands-on activities.

During these sessions, we modeled different teaching strategies. We encouraged the school librarians to use these methods in their own settings. During many of the meetings, the librarians worked on collaborative projects with partners or in small groups for a specified time period and then shared their results with the larger group. Creating inquiry and research project and strategies for initiating collaborative planning with teachers were topics addressed in a variety of ways during these meetings.

Many of the librarians were new to the field and had a limited knowledge of children's literature. We addressed this need in several ways. Our staff-prepared book talks focusing on a theme were a regular feature of most monthly meetings. In addition, we held an annual meeting in one of the major public libraries. Our staff introduced a genre or subject 
with a book talk, discussed the criteria for selecting such books, and then the librarians went to the shelves and chose books to share with their small groups, introducing the books in creative ways and explaining how the books met the criteria for the specific category.

We wanted librarians to hold book discussion groups in their school libraries, so we facilitated book discussion workshops. Librarians read the four or five assigned books on selected themes, came prepared to discuss the books and then adapted the process for their own schools.

For the past two years we featured a "Literature Day." Noted children's authors and illustrators discussed their work, and librarians presented projects they did with teachers. This year, Karen Hesse, winner of the Newbery and Scott O'Dell award and her editor discussed the "Craft of Writing for Children." Subsequently five simultaneous workshops led by school librarians addressed such topics as "Developing an Authentic Voice in Writing Reports, "Examining the Writing Styles in Selected Newbery Winning Books as a Basis for Improving Student Writing," and "Creating Books Based on Folklore Themes."

New York City schools recently adopted performance-based standards for English Language Arts. The "Literature Day" presentations benefited teachers and librarians who work together developing reading and writing projects that help students meet the rigorous new benchmarks. Last year's program "Illustration in Children's Books" which featured noted illustrators, David Frampton, Arthur Ransome, and Chris Raschka, sent participants home with a wealth of intellectual and practical ideas for appreciating and using art in the library and classroom. This year's presentation rivaled it with innovative ways to help students improve their writing.

Since the funding for the Library Power program has ended, it is critical that the continuation of the principles of the program be continued at the school level and the district level. This has occurred already in a number of ways. Districts added additional schools that follow the flexible access model and continue the regular staff development program for librarians.

For example, one outgrowth of the Library Power program is that a school district initiated a bimonthly-monthly staff development program in which the Library Power-trained librarians take responsibility for planning and facilitating meetings for all the librarians in the district. Two to four librarians usually work together to create participatory staff development sessions on topics such as research and inquiry, library automation, and flexible scheduling.

\section{Individualized site visits}

Another important aspect of professional development was the on-site assistance given to every school in the program. A member of our staff was assigned to visit specific schools regularly. Our field librarians modeled reference and reader's advisory interviews with students, sat in on teacher-librarian collaboration conferences and encouraged librarians and teachers to push projects to a higher level of critical thinking. We provided individual instruction in collection development, and our hands-on approach involved pitching in to move furniture and books and other resources to create inviting environments. 
As we engaged in this physical work alongside the school librarians, we taught them to merchandise their resources, display student work, make the libraries more inviting and personal, and develop an atmosphere where children felt welcomed. Dull, crowded, inefficient spaces became cheerful, colorful sites.

In many libraries, a great deal of weeding and technical assistance in the areas of cataloging and circulation procedures were necessary. Many of our librarians were reluctant to weed, because financial resources had been so limited. Others were afraid that their administrators would not understand how a librarian could discard books. Some simply thought all books could be useful, whether or not they were tattered and torn, inaccurate, or simply uninteresting to the children. We had a great deal of educating to do in this area. One of the ideas that we initiated was to have groups of librarians get together to weed at one school. This led one of our districts to use this concept in schools that were not part of the project. Large work groups weeded older collections and shelved all the books in brand new schools, in just one day.

We also encouraged "buddy" librarian relationships. This helped us to spread our resources among a wider group of libraries. The mentor librarians received a small grant for library resources and their administrators released them to go to their buddy schools and assist in weeding, room arrangement, initiating flexible schedules and developing collaborative teaching projects. Our field librarians visited these schools on a very limited basis, although they were available via phone and at monthly meetings. The mentor librarians were also available by phone and this was another unique aspect of our program.

By encouraging interpersonal relationships, both among the school librarians who were part of our network, and also between the school librarians and our staff members, we created a network of people who supported each other and contributed to lasting change. Because our staff was available by telephone at night and on weekends, we often received calls asking for help to create orders due immediately, for assistance in writing grants, for ideas for collaborative lesson plans with reluctant teachers who might not have been ready to participate, and for requests for staff development workshops. Of course, many of these calls could have been made during office hours, but our staff was in the field most of the time and until recently, many of the librarians did not have phones in their libraries.

E-mail began to replace these phone calls and librarians increasingly called upon each other to solve problems and to share ideas. Because monthly meetings were held all over the city the librarians carpooled or traveled together, and this created many personal and professional relationships. Networking became an active part of our librarians' working lives. In the past, librarians were often isolated. Now, the librarians in our project not only had access to our staff, but to a large number of "consultants" all over the city.

\section{Book exhibit}

During the first year of the project we scheduled a one week book exhibit that was held in a central location and displayed books, periodicals and videos. The exhibit was created by a company which up until then had only showed publishers' books at large professional conferences. Resources from a broad range of publishers were organized by subject area and an order list was provided. In recent years, we added software and computers to the exhibit for previewing purposes. The librarians in our project had few opportunities to see 
large quantities of new books without sales people urging them to buy their products. The "library" arrangement was very useful in assisting them to compare several books on the same topic. Our staff was available to suggest titles and assist individuals, and the librarians learned a great deal from each other. Librarians spent at least one full day at the exhibit and many came for several days. This, for many, was the highlight of the annual professional development offerings.

\section{Training In technology}

Although technology was not a factor of the project when we began, it took on increased importance as we aged and grew. Library Power librarians often were the first in their districts to gain access to computers, CD-ROM drives, the Internet, multimedia production tools, distance learning satellites, and other technological resources. We had to train the librarians who were often given these tools without staff development.

In 1994, New Visions developed a program that linked volunteers who provided technology services to school libraries. This program, known as AmeriCorps, is a United States government service program which provides stipends and scholarship funds for volunteers who make a commitment to public service for a one-year period. The AmeriCorps "technical coordinators" worked with the librarians to teach students, teachers and parents to use the technology available in their schools. The volunteers offered staff development to the librarians as well, through direct teaching and modeling. It was a reciprocal arrangement since the librarians taught the volunteers how to work with students and teachers, and how to use the library to increase student learning. Most of the Library Power libraries now have from two ten computers. Many have Internet access and a growing number have automated catalogs.

We hired an additional staff member with special expertise in technology, but our professional library staff still handled much of the for automation. Although some technical assistance was available from district technology coordinators and the automation vendors, we found it necessary to supplement their services. Sometimes this was accomplished during individual site visits, at other times we set up small workshops for people with similar problems in the automation process.

We encouraged schools to establish technology teams that explored all the issues of transforming schools into " $21^{\text {st }}$ century" learning centers. Our staff members and AmeriCorps technical coordinators helped schools develop technology plans that would make technology an integral part of teaching and learning in the library and the classroom. (Attachment: Technology staff development)

\section{Reaching out to teachers}

Technology was an excellent hook to reach teachers. We set up sessions for Internet training for librarians and teachers wishing to work on collaborative projects. It is often difficult to involve teachers in professional development during the school day because of the need to provide substitute teachers for their classes. Many of these sessions took place near the end of the school day and continued for an hour after school thereby eliminating the need for substitutes. 
Teachers were always invited to our book exhibits and some schools sent more than one. Reading specialists and language teachers viewed books on their areas of specialization while librarians examined other curriculum subjects. The teachers who attended the exhibit were pleased to review the more than 4,000 books in the collection, particularly since there was no other comparable experience available for them.

We worked with teachers during faculty meetings, grade level meetings and at special days set aside by the schools for staff development. Early on, we realized that faculty meetings were too rushed and filled with other concerns to be an effective time for our staff to address teachers and administrators. We encouraged administrators to create common preparation periods to enable teachers on the same grade level to meet together. The school librarians then could meet with all grades. Our staff often planned site visits to coincide with some of these meetings. We sometimes made formal presentations but more often we informally offered suggestions and assistance.

Staff members also worked on long-term projects in the library with teachers and librarians. One particularly successful endeavor brought artists into the libraries who developed book projects with classes. The artist concentrated on working with children on the illustrations while the teacher and librarian worked on writing and editing. The librarian and classroom teacher gained a great deal of insight as a result of these sessions and used these experiences to help other staff replicate or adapt these projects. Although our primary focus was on the professional growth and development of the school librarian, we realized that librarians could not do their jobs effectively without the involvement of teachers.

\section{Professional development for administrators}

Library Power Institutes were one- or two-day learning opportunities for teams that included librarians, parents, teachers and most importantly, administrators. These institutes featured organized visits to schools with exemplary library programs; presentations by invited consultants and/or New York City administrators; and discussion groups for teachers, librarians, administrators, and parents. Our purpose was to give administrators time away from the regular school day to reflect on issues related to the library program and to have opportunities to discuss these issues with their own school staff and their peers. Providing time for reflection created an atmosphere where the principles of the Library Power program could take root.

The National Library Power program, affiliated with the American Association of School Librarians and the Public Education Network (a national organization of not-for-profit educational organizations), sponsored annual conferences. District library coordinators, district superintendents, principals, librarians and district board members attended. Conference included visits to Library Power schools and gave participants an opportunity to meet with colleagues from across the nation to discuss the implementation of the Library Power model.

\section{Lessons learned}

After eight years of administrating this innovative program we have learned many lessons from both our successes and failures that may be valuable to librarians in other situations. 
These lessons have to do with expanding the mind sets of school librarians and the people with whom they work. These lessons present a picture of how to bring libraries and librarians into the center of teaching and learning in schools.

\section{End the isolation of the librarian}

Many of the school library media specialists felt deep sense of isolation. The position of librarian is usually the only one in a school. The librarians usually were not part of a professional group in their city, state or national organizations. Their local school districts did not have regular meetings where librarians from different schools could come together and discuss professional issues and the city school library system staff development office had no more than two meetings a year.

Our monthly staff development meetings taught professional skills but, even more importantly, they brought librarians together to share successes, and find strategies to overcome difficult situations. Their professional concerns were validated by others who had the same concerns. and together they would begin to address these concerns.

In addition, since the meetings were held in different libraries each month, it gave librarians an opportunity to see how others used their space and how they developed their collections. The meetings also gave many librarians their first experience in presenting curriculum projects to their colleagues which they then used in larger venues.

It is clear to us that librarians need to find opportunities to network with colleagues on a regular basis. Yearly conferences are one way to do so, but ongoing communication with librarians in one's own community is a necessity to insure ongoing professional growth and engagement. If there is no mechanism in place to bring people together, individuals should create the mechanism themselves. Informal meetings after school hours on a regular basis may pay off in greater knowledge, camaraderie and possibly better work for all involved.

\section{To improve library programs: involve teachers, administrators, parents}

Although we started working only with librarians, it became increasingly clear that librarians, on their own, usually could not change an entire school's climate. Working with individual teachers who were receptive to a new concept of collaboration was a good place to start, but if we wanted to affect the whole school, teachers, administrators and parents had to be brought into the staff development process. We facilitated meetings in which the librarians and teachers planned student projects and brought teachers more fully into the collection development process. These two strategies deepened the connection between teachers and librarians. Conferences and meetings were designed specifically for administrators, some of them in partnership with the school librarian, other school staff members and parents. Parent volunteers were welcomed at any workshop we offered to librarians and we led a number of parent workshops on library related topics.

Another effective technique was a school evaluation of the library media program. Developed by New Visions for Public Schools, school staff responded to a questionnaire and the results were measured against national standards. This tool gave participants a way to evaluate their school library. A facilitator from New Visions helped schools interpret the results and plan strategies to improve their library resources and services. 
We learned that not only did teachers need to be involved in staff development with librarians, the reverse was also true. Librarians needed to be included in teachers' staff development. When a new initiative was introduced to the school, teachers and librarians needed to learn together. Librarians needed to feel that even though they were not directly involved with a new tool or program, they should be conversant with it so they could support teachers' efforts.

In our schools, where so many children are not achieving at high academic levels, special literacy programs have been introduced in schools and new performance standards are being introduced to all teachers. The most successful librarians seek out opportunities to join their colleagues in professional development and in working with them to write and implement new curricula.

Our experience and that of other Library Power programs in the United States shows that the most effective approach to building understanding and support of the school library is a multifaceted one that brings the school community together, not only around issues that pertain directly to the library, but also on all issues of teaching and learning. The librarian who is a full teaching partner will also lead colleagues to a consensus that the library is the hub of the school. Key to this understanding is an administrator who supports and has high expectations for collaboration between teachers and librarians and who provides the time and structure for planning that is essential to good collaboration.

\section{Flexible scheduling/open access}

We found that a library that is open to the school community throughout the school day and for extended hours is the most effective model. The flexible schedule fosters the idea that the library is used for multiple purposes, frequently with small groups or individuals from different classes using the resources for different purposes. Students and teachers can plan to come to the library on an as-needed basis and for multiple times in a short period of time for specific work. Access to the library for individuals allows students to be responsible for their work and their reading needs. A child who has finished a book can come to the library as soon as she wants to get another and does not have to wait for her class to come to exchange her book.

The flexible model where the librarian is not responsible for teaching a class of students by herself creates the possibility of a team teaching situation where both the librarian and the teacher work with the students, each contributing her strengths to the teaching process.

\section{Improvement in the physical space pays off}

An often overlooked but powerful way to change staff perceptions about the library is to rejuvenate the space. Even small, but significant, changes make a difference. The easiest and least expensive method is to rearrange the existing furniture, get rid of the clutter, weed the shelves and then display the collection in an eye catching manner. An attractive makeover invites people into the space and creates an atmosphere of vitality that can be the catalyst for deeper more programmatic change. Painting the library in bright attractive colors says "something new is going on ... come join us." 
"One-shot" workshops, although worthwhile, are not effective in achieving long-term results

A major lesson we learned as we designed workshops was that if we want to effect real change in practice, staff development workshops need to be focused on essential themes and should relate to each other. Workshops that bring in a guest speaker, for instance, require follow-up to ensure that the content is understood and applied in practice. Workshops should build upon each other and connections have to be made to past and future sessions.

Our major themes were increasing student literacy, collection development, developing collaborative teaching relationships with school staff that result in higher student achievement, and integrating technology into the curriculum. Workshops were structured around the experience of the participants and care was taken to tailor content to the level of expertise of the participants whenever possible. Our least successful sessions were those in which participants either had not enough knowledge to understand the content or the content was not sufficiently challenging. The longer we administered the program, the more differentiated the professional development meetings became.

\section{Communication, communication, communication}

Public relations communicates the library's services, programs and goals to the school community and the community at large. Presentations by students, celebrations, school-wide literary events, visual displays in the hallways, videos highlighting a particular program and shown on public access TV, newsletters, web pages, public appearances, presentations at state and national conferences, and writing for professional publications were some of the ways librarians brought attention to their work. The librarians who were successful at creating opportunities to show the value of their programs brought favorable attention which frequently resulted in additional financial and educational support and contributed to the efforts to continue the Library Power model beyond the grant period. We all know that this is an important area that is often neglected, but librarians found that by bringing more people such as parents and students into the process, the work was distributed and the end results were well worth the effort.

\section{Conclusion}

By working with librarians, teachers, and administrators, Library Power created library programs that have had a strong impact upon teaching and learning. By professionalizing librarians' attitudes towards their jobs, we have been instrumental in developing a group of school librarians in New York City who can lead colleagues as they implement programs that stimulate student inquiry, integrate technology in the curriculum, engage students in higher levels of literacy, and promote collaboration between school librarians and teachers throughout the school. We believe that librarians can increase their impact on their own situations, and that they and their administrators can adapt many of our strategies as they move forward to provide better learning experiences for all their students through libraries. 